\title{
ANALISA INSENTIF DAN KEPEMIMPINAN TERHADAP KINERJA KARYAWAN DI PT BINA SAN PRIMA
}

\author{
Sumarsid \\ Dosen Tetap Sekolah Tinggi Manajemen Labora \\ labora@labora.ac.id
}

\begin{abstract}
ABSTRAK
Pada analisa data ini, penulis mengumpulkan data yang dapat mendukung penelitian dengan cara menyebarkan kuesioner kepada 50 orang responden dari seluruh karyawan tetap (staff) di PT Bina San Prima, dengan hasil penelitian diantaranya : Hasil analisa koefisien korelasi berganda didapatkan nilai koefisien korelasi berganda $X_{1}$ (Insentif) dan $X_{2}$ (Kepemimpinan) adalah 0.717, dengan demikian Insentif dan Kepemimpinan berpengaruh kuat terhadap Kinerja karyawan di PT Bina San Prima.

Dari analisa koefisien penentu (KP) didapat hasil sebesar 0,515 dengan demikian Insentif dan Kepemimpinan memiliki kontribusi sebesar 51,5\% terhadap Kinerja karyawan di PT Bina San Prima, dan sisanya sebesar 48,5\% dipengaruhi oleh faktor-faktor lain yang tidak penulis teliti, misalnya, beban kerja, motivasi, dan pelatihan. Uji hipotesis dengan uji $F$ didapatkan nilai sig. $F$ hitung sebesar $0.000<5 \%, \quad(0.000<0.005)$ sehingga dapat disimpulkan bahwa : Insentif dan Kepemimpinan secara simultan berpengaruh signifikan terhadap Kinerja karyawan di di PT Bina San Prima. Sedangkan berdasarkan uji hipotesis dengan uji $t$ didapatkan nilai signifikan masing-masing 0,003 dan $0.013<0.05$ sehingga dapat disimpulkan bahwa: Insentif secara parsial berpengaruh signifikan terhadap kinerja karyawan di PT Bina San Prima, demikian juga dengan Kepemimpinan secara parsial berpengaruh signifikan terhadap kinerja karyawan di PT Bina San Prima.

Sedangkan berdasarkan hasil analisis regresi linier berganda didapatkan persamaan $Y$ $=23.701+0.264 X_{1}+0.308 X_{2}$, Dalam persamaan regresi tersebut diketahui konstantanya adalah 23.701 ini dapat diartikan bahwa tanpa adanya Insentif $\left(X_{1}\right)$, dan Kepemimpinan $\left(X_{2}\right)$, maka kinerja karyawan $(Y)$ menunjukkan nilai sebesar 23.701 poin/satuan. Berdasarkan kesimpulan di atas maka saran-saran yang dapat penulis berikan melalui hasil penelitian ini di antaranya sebagai berikut : Dari hasil penelitian di dapat indikasi kelemahan pada variabel insentif pada indikator insentif yang diberikan sudah sesuai dengan beban dan tanggung jawab. Diharapkan insentif yang diberikan lebih disesuaikan lagi dengan beban dan tanggung jawab pada masing-masing karyawan. Serta diharapkan dari indikator apresiasi pemimpin atau atasan dapat memberikan penghargaan atau reward kepada para karyawan yang telah berkontribusi besar atau berprestasi atas kinerjanya.
\end{abstract}

Kata Kunci : Insentif, Kepemimpinan dan Kinerja

\section{A. PENDAhuluan}

Kinerja karyawan yang baik adalah salah satu faktor yang sangat penting dalam upaya untuk meningkatkan produktivitas. Oleh karena itu, salah satu cara terbaik untuk meningkatkan kinerja karyawan adalah dengan memberikan insentif yang adil kepada karyawan serta peran seseorang yang mempunyai gaya 
kepemimpinan yang bisa memberikan wewenang dan tanggung jawab sesuai dengan jabatan, tugas dan fungsinya dengan sebaik mungkin untuk mencapai tujuan dan mempertahankan kelangsungan hidup perusahaan. PT Bina San Prima sebagai sebuah perusahaan yang bergerak dibidang distribusi pelayanan kesehatan nasional, produk konsumen dan bahan baku distributor harus mampu membangun kredibilitas dan kinerjanya secara baik kepada klien maupun principal untuk menjaga kualitas pelayanannya. Kredibilitas dan kinerja yang baik ditentukan oleh seberapa baik kinerja karyawan dari PT Bina San Prima dalam melaksanakan tugasnya. Agar kegiatan di PT Bina San Prima berjalan optimal tentunya harus dapat memberikan insentif yang layak kepada para karyawan, sehingga mereka dapat bekerja secara produktif ditambah hubungan antara pimpinan dan bawahan harus terjaga dengan baik agar dapat menciptakan produktivitas dan kepuasan kerja yang tinggi.

Berdasarkan uraian diatas, maka penulis tertarik untuk meneliti apakah pemberian insentif dan kepemimpinan berpengaruh signifikan baik secara parsial maupun simultan terhadap kinerja karyawan di PT Bina San Prima?

\section{Asumsi}

Agar tidak mengandung persepsi yang salah terhadap permasalahan yang akan dibahas dalam penelitian ini maka, asumsi sebagai berikut : Pemberian insentif dan kepemimpinan dilakukan melalui mekanisme yang transparan dan memenuhi unsur keadilan, Gaya kepemimpinan yang diteliti adalah gaya kepemimpinan yang mengarah pada produktivitas karyawan dan Penilaian kinerja sudah dilakukan sesuai prosedur yang berlaku dan objektif.

\section{B. LANDASAN TEORI}

\section{Manajemen Sumber Daya Manusia}

Aset paling penting yang harus dimiliki oleh organisasi atau perusahaan dan harus diperhatikan dalam manajemen adalah tenaga kerja atau manusia (sumber daya manusia). Terminologi sumber daya manusia (human resources) merujuk kepada orang-orang yang bekerja di dalam organisasi. Menurut Malayu S.P. 
Hasibuan dalam bukunya Manajemen Sumber Daya Manusia, (2008, h.10 )"Manajemen Sumber Daya Manusia adalah "Ilmu dan seni yang mengatur hubungan dan peranan tenaga kerja agar efektif dan efisien membantu terwujudnya tujuan perusahaan, karyawan dan masyarakat”.

Pengertian manajemen Sumber Daya Manusia yang diberikan oleh A.A. Anwar Parabu Mangkuprawira dalam bukunya Manajemen Sumber Daya Manusia Perusahaan, (2013, p. 2) ialah : "Manajemen sumber daya manusia merupakan suatu perencanaan, pengorganisasian, pengkoordinasian, pelaksanaan, dan pengawasan terhadap pengadaan, pengembangan, pemberian balas jasa, pengintegrasian, pemeliharaan, dan pemisahan tenaga kerja dalam rangka mencapai tujuan organisasi”.

Berdasarkan

pengertianpengertian diatas, manajemen sumber daya manusia di perusahaan perlu di kelola secara profesional agar terwujud keseimbangan antara kebutuhan pegawai dengan tuntutan dan kemampuan organisasi perusahaan. Dengan pengaturan manajemen sumber daya manusia secara profesional, diharapkan pegawi bekerja secara optimal. Pengelolaan pegawai secara profesional ini harus dimulai sejak perekrutan pegawai, penyeleksian, pengklarifikasian, dan penempatan pegawai sesuai dengan kemampuan penataran, dan pengembangan kariernya.

\section{a) Pengertian Insentif}

Untuk mendapatkan pengertian yang lebih jelas mengenai insentif, di bawah ini ada beberapa ahli yang mengemukakan pendapat mengenai apa yang dimaksud dengan insentif. Menurut Handoko (2008, h.176) Insentif adalah perangsang yang ditawarkan kepada para karyawan untuk melaksanakan kerja sesuai atau lebih tinggi dari standar-standar yang telah ditetapkan. Sedangkan Menurut Hasibuan (2008, h.117) Insentif adalah tambahan balas jasa yang diberikan kepada karyawan tertentu yang prestasinnya di atas prestasi standar. Insentif ini merupakan alat yang dipergunakan pendukung prinsip adil dalam pemberian kompensasi dan Menurut Mangkunegara (2010, h.89) Insentif adalah suatu bentuk motivasi yang dinyatakan dalam bentuk uang 
atas dasar kinerja yang tinggi dan juga merupakan rasa pengakuan dari pihak organisasi terhadap kinerja karyawan dan kontribusi terhadap organisasi (perusahaan).

Dari keseluruhan definisi diatas, maka dapat penulis simpulkan bahwa insentif adalah dorongan pada seseorang agar mau bekerja dengan baik dalam arti lebih produktif agar tujuan yang ingin dicapai oleh perusahaan dapat terpenuhi dan karyawan mendapatkan kesempatan bagi pemuasan kebutuhan mereka.

Adapun kebutuhan - kebutuhan menurut Kevin Davis sebagai berikut :

1) Phsycological needs atau kebutuhan - kebutuhan fisik adalah kebutuhan badaniah yang meliputi sandang, pangan, papan serta biologis.

2) Safety and security needs adalah kebutuhan hidup yang meliputi baik keamanan jiwa maupun keamanan harta benda.

3) Social and belonging needs merupakan kebutuhan yang meliputi kebutuhan akan rasa dihormati, kebutuhan perasaan maju atau berprestasi dan kebutuhan akan perasaan keikutsertaan.

4) Esteem and status needs adalah kebutuhan - kebutuhan akan penghargaan dari orang lain terhadap kita.

5) Self actualization and fulfillment needs adalah kebutuhan akan kepuasan yang di dapat dari pekerjaan.

Berdasarkan hal-hal diatas, dapat dikatan bahwa semakin karyawan itu terpuaskan oleh kebutuhan - kebutuhan yang diberikan oleh perusahaan, maka para karyawan akan semakin terdorong untuk segera menyelesaikan dan mencapai segala apa yang menjadi tugas dan semua tanggung jawabnya. Dengan kata lain, pemberian insentif yang teratur oleh perusahaan ditujukan agar para karyawan lebih dapat meningkatkan kinerja untuk mencapai tujuan perusahaan.Indikator penelitian yang digunakan dalam variabel $\mathrm{X}_{1}$ mengenai insentif mengacu pada teori dari Hasibuan (2008, h.94) adalah sebagai berikut: 
Tabel

Indikator Insentif

\begin{tabular}{|c|l|l|c|}
\hline Variabel & \multicolumn{1}{|c|}{ Definisi Variabel } & \multicolumn{1}{|c|}{ Indikator } & \multicolumn{1}{c|}{$\begin{array}{c}\text { Skala } \\
\text { pengukuran }\end{array}$} \\
\hline & Insentif adalah tambahan & a. Kinerja & \\
balas jasa yang diberikan & b. Lama kerja & \\
Insentif & kepada karyawan tertentu & c. Senioritas & \multirow{2}{*}{ Skala Likert } \\
$\left(\mathrm{X}_{1}\right)$ & yang prestasinya diatas & d. Kebutuhan & \\
& prestasi standar. & e. Keadilan \& & kelayakan \\
& & f. evalasi jabatan & \\
\hline
\end{tabular}

Sumber : Hasibuan (2008, h.94)

\section{b) Pengertian Kepemimpinan}

Kepemimpinan

adalah

seseorang yang memiliki kemampuan mempengaruhi perilaku orang lain. Kepemimpinan juga merupakan masalah sentral dalam kepengurusan organisasi. Maju mundurnya organisasi, dinamis statisnya organisasi, tumbuh kembangnya organisasi, mati hidupnya organisasi, senang tidaknya seseorang bekerja dalam suatu organisaasi, serta tercapai tidaknya tujuan organisasi, sebagian ditentukan oleh tepat tidaknya kepemimpinan yang diterapkan dalam organisasi yang bersangkutan.

Berikut ini akan penulis uraikan pengertian kepemimpinan menurut ahli diantaranya menurut George R. Terry dalam buku Sedarmayanti Manajemen Sumber Daya Manusia (2009, p. 264) mengemukakan : "Kepemimpinan adalah keseluruhan kegiatan atau aktivitas untuk mempengaruhi kemauan orang lain untuk mencapai tujuan bersama". Sedangkan Menurut Sadili Samsudin, (2006, hal 287) mengemukakan: "Kepemimpinan dengan kemampuan meyakinkan dan menggerakkan orang lain agar mau bekerja sama di bawah kepemimpinannya sebagai suatu tim untuk mencapai suatu tujuan tertentu".Sedangkan menurut Kartini Kartono, dalam bukunya "Pemimpin dan Kepemimpinan” (2008, hal 6) mengemukakan: "Kepemimpinan adalah masalah relasi dan pengaruh antara pemimpin dengan yang dipimpin".

Dari beberapa definisi di atas dapat disimpulkan bahwa kepemimpinan adalah kemampuan untuk menpengaruhi dan menggerakan orang lain untuk mencapai tujuan. Kepemimpinan dalam organisasi diarahkan untuk mempengaruhi orang - orang yang dipimpinnya, agar mau 
berbuat seperti yang diharapkan memimpinnya.

ataupun diarahkan oleh orang yang

Tabel

Indikator Kepemimpian

\begin{tabular}{|c|c|c|c|}
\hline Variabel & Definisi Variabel & Indikator & $\begin{array}{c}\text { Skala } \\
\text { pengukuran }\end{array}$ \\
\hline Kepemimpinan $\left(\mathrm{X}_{2}\right)$ & $\begin{array}{l}\text { kepemimpinan adalah kemampuan } \\
\text { seseorang untuk mempengaruhi } \\
\text { orang lain dalam hal bawahannya, } \\
\text { sedemikian rupa sehingga orang } \\
\text { lain itu mau melakukan kehendak } \\
\text { pimpinan, meskipun secara pribadi } \\
\text { hal itu mungkin tidak } \\
\text { disenanginya. }\end{array}$ & $\begin{array}{l}\text { a. Kepercayaan } \\
\text { b. Apresiasi } \\
\text { c. Pertimbangan perasaan } \\
\text { d. Kenyamanan kerja } \\
\text { e. Kesejahteraan } \\
\text { f. Pengakuan } \\
\text { g. Kepuasan kerja karyawan }\end{array}$ & Skala Likert \\
\hline
\end{tabular}

Sumber : Siagian (2007, h.121-122)

c) Pengertian Kinerja

Kinerja dalam bahasa

Indonesia sebenarnya terjemahan secara bebas dari kata performance.

Kinerja dalam arti sering digunakan untuk mengukur pencapaian kerja seseorang seperti tugas kepada seseorang dalam organisasi. Menurut Malayu S.P. Hasibuan : "Kinerja (prestasi kerja) adalah satu hasil kerja yang dicapai seseorang dalam melaksanakan tugas-tugas yang dibebankan kepadanya yang didasarkan atas kecakapan, pengalaman dan kesungguhan serta waktu”. Menurut Mangku Negara, (2005, p 9) mengemukakan : "Pengertian kinerja adalah hasil kerja secara kualitas dan kuantitas yang dicapai oleh seseorang karyawan dalam melaksanakan tugasnya sesuai dengan tanggung jawab yang diberikan kepadanya".

Sedangkan menurut Moh. Pabunda Tika, (2008, p 121) mengemukakan: "Kinerja adalah sebagai hasil-hasil fungsi pekerjaan/kegiatan seseorang atau kelompok dalam suatu organisasi yang dipengaruhi oleh berbagai faktor untuk mencapai tujuan organisasi dalam periode waktu tertentu". Seseorang harus memiliki derajat kesediaan dan tingkat kemampuan tertentu. Kesediaan dan keterampilan seseorang tidaklah cukup efektif untuk mengerjakan sesuatu tanpa pemahaman yang jelas tentang apa yang akan dikerjakan dan bagaimana mengerjakannya. 
Tabel

Indikator Kinerja Karyawan

\begin{tabular}{|c|c|c|c|}
\hline Variabel & Definisi Variabel & Indikator & $\begin{array}{c}\text { Skala } \\
\text { pengukuran }\end{array}$ \\
\hline $\begin{array}{c}\text { Kinerja Karyawan } \\
\text { (Y) }\end{array}$ & $\begin{array}{l}\text { Kinerja adalah tingkat dimana } \\
\text { pegawai melaksanakan } \\
\text { pekerjannya sesuai dengan } \\
\text { syarat-syarat yang telah } \\
\text { ditentukan }\end{array}$ & $\begin{array}{l}\text { a. Kualitas kerja } \\
\text { b. Kuantitas kerja } \\
\text { c. Kemandirian } \\
\text { d. Inisiatif } \\
\text { e. Adaptabilitas } \\
\text { f. Kerjasama }\end{array}$ & Skala Likert \\
\hline
\end{tabular}

Sumber : Priansa (2014, h.271)

C. ANALISA DATA DAN

PEMBAHASAN

\section{a. Uji Validitas}

Teknik yang digunakan untuk uji validitas ini adalah "korelasi product moment" dari Pearson dengan tingkat kepercayaan $95 \%(\alpha=0,05)$ dilakukan dengan cara mengkorelasikan skor masing-masing item dengan $r$ hitung > $r$ tabel dan $n=50$.

Tabel

Hasil Pengujian Validitas

\begin{tabular}{|c|c|c|c|c|c|}
\hline No & $\begin{array}{c}\text { Butir Dalam } \\
\text { Kuesioner }\end{array}$ & $\begin{array}{c}\text { Koefisien } \\
\text { Korelasi (r) }\end{array}$ & $\begin{array}{c}\text { Nilai Kritis } \\
\text { (r-tabel) }\end{array}$ & $\begin{array}{l}\text { Taraf Sig. } \\
(\alpha=0,05)\end{array}$ & Keterangan \\
\hline 1 & $\mathrm{X} 1.1$ & 0.804 & 0,279 & 0.000 & Valid \\
\hline 2 & $\mathrm{X} 1.2$ & 0.738 & 0,279 & 0.000 & Valid \\
\hline 3 & $\mathrm{X} 1.3$ & 0.880 & 0,279 & 0.000 & Valid \\
\hline 4 & X1.4 & 0.851 & 0,279 & 0.000 & Valid \\
\hline 5 & $\mathrm{X} 1.5$ & 0.906 & 0,279 & 0.000 & Valid \\
\hline 6 & $\mathrm{X} 1.6$ & 0.825 & 0,279 & 0.000 & Valid \\
\hline 7 & $\mathrm{X} 1.7$ & 0.855 & 0,279 & 0.000 & Valid \\
\hline 8 & $\mathrm{X} 2.1$ & 0.577 & 0,279 & 0.000 & Valid \\
\hline 9 & $\mathrm{X} 2.2$ & 0.626 & 0,279 & 0.000 & Valid \\
\hline 10 & $\mathrm{X} 2.3$ & 0.718 & 0,279 & 0.000 & Valid \\
\hline 11 & $\mathrm{X} 2.4$ & 0.832 & 0,279 & 0.000 & Valid \\
\hline 12 & $\mathrm{X} 2.5$ & 0.546 & 0,279 & 0.000 & Valid \\
\hline 13 & $\mathrm{X} 2.6$ & 0.773 & 0,279 & 0.000 & Valid \\
\hline 14 & $\mathrm{X} 2.7$ & 0.686 & 0,279 & 0.000 & Valid \\
\hline 15 & $\mathrm{X} 2.8$ & 0.607 & 0,279 & 0.000 & Valid \\
\hline 16 & $\mathrm{X} 2.9$ & 0.707 & 0,279 & 0.000 & Valid \\
\hline 17 & Y.1 & 0.720 & 0,279 & 0.000 & Valid \\
\hline 18 & Y.2 & 0.565 & 0,279 & 0.000 & Valid \\
\hline 19 & Y.3 & 0.676 & 0,279 & 0.000 & Valid \\
\hline 20 & Y.4 & 0.707 & 0,279 & 0.000 & Valid \\
\hline 21 & Y.5 & 0.691 & 0,279 & 0.000 & Valid \\
\hline 22 & Y.6 & 0.612 & 0,279 & 0.000 & Valid \\
\hline 23 & Y.7 & 0.575 & 0,279 & 0.000 & Valid \\
\hline 24 & Y.8 & 0.629 & 0,279 & 0.000 & Valid \\
\hline 25 & Y.9 & 0.579 & 0,279 & 0.000 & Valid \\
\hline 26 & Y.10 & 0.580 & 0,279 & 0.000 & Valid \\
\hline
\end{tabular}

Sumber : Hasil Pengolahan Data 
Dari data-data pada tabel di atas, diketahui bahwa tidak ada butir pernyataan yang gugur atau tidak valid, karena mempunyai nilai koefisien korelasi $(r) \geq 0,279$, sehingga dapat disimpulkan bahwa seluruh butir pernyataan dalam kuesioner penelitian adalah valid.

\section{b. Uji Reliabilitas}

Metode untuk mengukur reliabilitas adalah dengan melihat nilai alpha cronbach's. Suatu variabel dikatakan reliabel apabila nilai alpha cronbach's $\geq 0,6$.

Tabel

Hasil Pengujian Reliabilitas

\begin{tabular}{|c|c|c|c|c|}
\hline No & $\begin{array}{c}\text { Butir Dalam } \\
\text { Kuesioner }\end{array}$ & $\begin{array}{c}\text { Cronbach's Alpha if } \\
\text { Item Deleted }\end{array}$ & $\begin{array}{c}\text { Cronbach's } \\
\text { Alpha }\end{array}$ & Status \\
\hline 1 & X1.1 & 0.773 & 0,6 & Reliabel \\
\hline 2 & $\mathrm{X} 1.2$ & 0.783 & 0,6 & Reliabel \\
\hline 3 & $\mathrm{X} 1.3$ & 0.762 & 0,6 & Reliabel \\
\hline 4 & $\mathrm{X} 1.4$ & 0.768 & 0,6 & Reliabel \\
\hline 5 & $\mathrm{X} 1.5$ & 0.767 & 0,6 & Reliabel \\
\hline 6 & $\mathrm{X} 1.6$ & 0.772 & 0,6 & Reliabel \\
\hline 7 & $\mathrm{X} 1.7$ & 0.766 & 0,6 & Reliabel \\
\hline 8 & $\mathrm{X} 2.1$ & 0.752 & 0,6 & Reliabel \\
\hline 9 & $\mathrm{X} 2.2$ & 0.747 & 0,6 & Reliabel \\
\hline 10 & $\mathrm{X} 2.3$ & 0.740 . & 0,6 & Reliabel \\
\hline 11 & $\mathrm{X} 2.4$ & 0.725 & 0,6 & Reliabel \\
\hline 12 & $\mathrm{X} 2.5$ & 0.755 & 0,6 & Reliabel \\
\hline 13 & $\mathrm{X} 2.6$ & 0.734 & 0,6 & Reliabel \\
\hline 14 & $\mathrm{X} 2.7$ & 0.744 & 0,6 & Reliabel \\
\hline 15 & $\mathrm{X} 2.8$ & 0.753 & 0,6 & Reliabel \\
\hline 16 & X2.9 & 0.741 & 0,6 & Reliabel \\
\hline 17 & Y.1 & 0.728 & 0,6 & Reliabel \\
\hline 18 & Y.2 & 0.737 & 0,6 & Reliabel \\
\hline 19 & Y.3 & 0.730 & 0,6 & Reliabel \\
\hline 20 & Y.4 & 0.729 & 0,6 & Reliabel \\
\hline 21 & Y.5 & 0.728 & 0,6 & Reliabel \\
\hline 22 & Y.6 & 0.733 & 0,6 & Reliabel \\
\hline 23 & Y.7 & 0.741 & 0,6 & Reliabel \\
\hline 24 & Y.8 & 0.737 & 0,6 & Reliabel \\
\hline 25 & Y.9 & 0.732 & 0,6 & Reliabel \\
\hline 26 & Y.10 & 0.730 & 0,6 & Reliabel \\
\hline
\end{tabular}

Sumber : Hasil Pengolahan Data

Dari data yang tertera pada tabel di atas, menunjukkan bahwa nilai cronbach's alpha ketiga variabel penelitian tersebut berada di atas nilai $r$ tabel pada taraf signifikan 5\%, dengan nilai alpha cronbach's $\geq 0,6$ dengan demikian dapat disimpulkan bahwa ketiga 
variabel penelitian tersebut adalah reliabel.

\section{c. Analisa Koefisien Korelasi}

Merupakan indeks atau bilangan yang digunakan untuk mengukur atau mengetahui kedekatan hubungan antara variabel yang disimbolkan dengan (r).

Tabel

Hasil Pengujian Koefisien Korelasi

Correlations

\begin{tabular}{|ll|r|r|r|}
\hline & & Insentif & Kepemimpinan & $\begin{array}{c}\text { Kinerja } \\
\text { Karyawan }\end{array}$ \\
\hline \multirow{5}{*}{ Insentif } & Pearson Correlation & 1 & $.665^{* *}$ & $.667^{* *}$ \\
& Sig. (2-tailed) & & .000 & .000 \\
& $\mathrm{~N}$ & 50 & 50 & 50 \\
Kepemimpinan & Pearson Correlation & $.665^{* *}$ & 1 & $.640^{* *}$ \\
& Sig. (2-tailed) & .000 & 50 \\
& $\mathrm{~N}$ & 50 & .000 \\
& Pearson Correlation & $.667^{* *}$ & $.640^{* *}$ & 50 \\
Kinerja Karyawan & Sig. (2-tailed) & .000 & .000 & 1 \\
& $\mathrm{~N}$ & 50 & 50 & 50 \\
\hline
\end{tabular}

**. Correlation is significant at the 0.01 level (2-tailed).

Sumber : Hasil Pengolahan Data

Dari data pada tabel di atas, didapatkan nilai koefisien korelasi $\mathrm{X}_{1}$ Insentif adalah 0.667, dan nilai koefisen korelasi $\mathrm{X}_{2} \quad$ Kepemimpinan adalah 0.640, dengan demikian Pemberian Insentif dan Kepemimpinan berpengaruh kuat dan signifikan $(0,000>$ 0,05) terhadap Kinerja karyawan di PT Bina San Prima.

\section{d. Analisa Koefisien Korelasi Berganda}

Analisis ini untuk menguji ada atau tidaknya hubungan yang signifikan secara simultan antara variabel Insentif $\left(\mathrm{X}_{1}\right)$ dan Kepemimpinan $\left(\mathrm{X}_{2}\right)$ terhadap variabel Kinerja karyawan (Y).

Tabel

Hasil Pengujian Koefisien Korelasi Berganda

Model Summary

\begin{tabular}{|l|r|r|r|rr|}
\hline Model & \multicolumn{1}{|c|}{$\mathrm{R}$} & R Square & \multicolumn{1}{|c|}{$\begin{array}{c}\text { Adjusted R } \\
\text { Square }\end{array}$} & \multicolumn{2}{|c|}{$\begin{array}{c}\text { Std. Error of the } \\
\text { Estimate }\end{array}$} \\
\hline 1 & $.717^{\mathrm{a}}$ & .515 & .494 & 2.461 \\
\hline
\end{tabular}

a. Predictors: (Constant), Kepemimpinan, Insentif

Sumber : Hasil Pengolahan Data 
Dari data pada tabel di atas, didapatkan nilai koefisien korelasi berganda $\mathrm{X}_{1}$ Pemberian Insentif dan $\mathrm{X}_{2}$ Kepemimpinan adalah 0.717 , dengan demikian Pemberian Insentif dan Kepemimpinan memiliki hubungan kuat terhadap Kinerja karyawan di PT Bina San Prima. e. Analisa Koefisien Penentu (Determinasi)

Analisa koefisien penentu atau Determinasi digunakan untuk mengetahui besarnya kontribusi dari variabel $\mathrm{X}_{1}$ Insentif dan variabel $\mathrm{X}_{2}$ Kepemimpinan terhadap Kinerja karyawan pada PT Bina San Prima sebagai variabel Y.

Tabel

Hasil Pengujian Koefisien Determinasi Model Summary

\begin{tabular}{|l|r|r|r|r|}
\hline Model & \multicolumn{1}{|c|}{$\mathrm{R}$} & R Square & \multicolumn{1}{|c|}{$\begin{array}{c}\text { Adjusted R } \\
\text { Square }\end{array}$} & \multicolumn{2}{|c|}{$\begin{array}{c}\text { Std. Error of the } \\
\text { Estimate }\end{array}$} \\
\hline 1 & $.717^{\mathrm{a}}$ & .515 & .494 & \\
\hline
\end{tabular}

a. Predictors: (Constant), Kepemimpinan, Insentif

Sumber : Hasil Pengolahan Data

Dari data yang tertera pada tabel di atas, menunjukkan bahwa nilai Koefisien Penentu/ Determinasi $\left(\mathrm{R}^{2}\right)$ adalah 0,515 dengan demikian Pemberian Insentif dan Kepemimpinan memiliki kontribusi sebesar $51,5 \%$ terhadap Kinerja karyawan di PT Bina San Prima, dan sisanya sebesar $48.5 \%$ dipengaruhi oleh faktorfaktor lain yang tidak penulis teliti.

\section{f. Pengujian Hipotesis dengan Uji F dan Uji T}

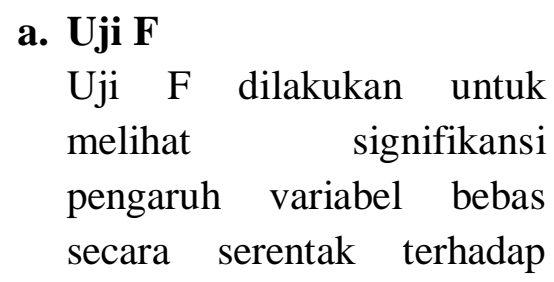

variabel terikat. Pengujian ini dilakukan dengan membandingkan nilai signifikan $\mathrm{F}$ hitung.

1. $\mathrm{Ho}=$ Pemberian insentif dan kepemimpinan secara simultan tidak berpengaruh signifikan terhadap kinerja karyawan di PT Bina San Prima

2. $\mathrm{Ha}=$ Pemberian insentif dan kepemimpinan secara simultan berpengaruh signifikan terhadap kinerja karyawan di PT Bina San Prima. 
Tabel

Hasil Uji F

ANOVA $^{\mathrm{a}}$

\begin{tabular}{|c|r|r|r|c|c|}
\hline Model & Sum of Squares & \multicolumn{1}{c|}{ df } & Mean Square & F & Sig. \\
\hline Regression & 301.801 & 2 & 150.901 & 24.912 & $.000^{\mathrm{b}}$ \\
Residual & 284.699 & 47 & 6.057 & & \\
Total & 586.500 & 49 & & & \\
\hline
\end{tabular}

a. Dependent Variable: Kinerja Karyawan

b. Predictors: (Constant), Kepemimpinan, Insentif

Sumber : Hasil Pengolahan Data

Berdasarkan tabel di atas diketahui bahwa signifikan variabel $\mathrm{X}_{1}$ yaitu Insentif serta variabel $\mathrm{X}_{2}$ Kepemimpinan adalah sebesar $0,000<0,05$ dengan demikian Ho ditolak dan $\mathrm{Ha}$ diterima, artinya secara simultan Pemberian Insentif serta Kepemimpinan berpengaruh signifikan terhadap Kinerja karyawan di PT Bina San Prima.

b. Uji t

Uji $\mathrm{t}$ dilakukan untuk melihat signifikansi pengaruh variabel bebas secara sendiri-sendiri (parsial) terhadap variabel terikat dengan menggangap variabel lain bersifat konstan. Pengujian ini dilakukan dengan membandingkan nilai sig. $\mathrm{t}$ hitung masing-masing variabel bebas. Adapun rumusan hipotesanya adalah sebagai berikut :

1. Ho = Pemberian insentif secra parsial tidak berpengaruh signifikan terhadap kinerja karyawan di PT Bina San Prima.

2. Ho $=$ Kepemimpinan secara parsial tidak berpengaruh signifikan terhadap kinerja karyawan di PT Bina San Prima.

3. $\mathrm{Ha}=$ Pemberian insentif secra parsial berpengaruh signifikan terhadap kinerja karyawan di PT Bina San Prima.

4. $\mathrm{Ha}=$ Kepemimpinan secara parsial berpengaruh signifikan terhadap kinerja karyawan di PT Bina San Prima. 
Tabel

Hasil Uji t

Coefficients $^{\mathrm{a}}$

\begin{tabular}{|c|c|c|c|c|c|}
\hline \multirow[t]{2}{*}{ Model } & \multicolumn{2}{|c|}{$\begin{array}{l}\text { Unstandardized } \\
\text { Coefficients }\end{array}$} & $\begin{array}{l}\text { Standardized } \\
\text { Coefficients }\end{array}$ & \multirow[t]{2}{*}{$\mathrm{t}$} & \multirow[t]{2}{*}{ Sig. } \\
\hline & $\mathrm{B}$ & Std. Error & Beta & & \\
\hline (Constant) & 23.701 & 3.183 & & 7.446 & .000 \\
\hline Insentif & .264 & .083 & .433 & 3.180 & .003 \\
\hline Kepemimpinan & .308 & .119 & .353 & 2.594 & .013 \\
\hline
\end{tabular}

a. Dependent Variable: Kinerja Karyawan

Sumber : Hasil Pengolahan Data

1. Berdasarkan hasil penelitian yang tertera pada tabel di atas, diketahui bahwa nilai signifikan variabel $\mathrm{X}_{1}$ Insentif adalah sebesar $0,003<5 \% \quad(0,003<$ $0,05)$, dengan demikian to $<$ ta maka $\mathrm{Ha}$ (hipotesis alternatif) diterima dan Ho (hipotesis nihil) ditolak. Artinya Insentif secara parsial berpengaruh signifikan terhadap kinerja karyawan di PT Bina San Prima.

2. Nilai signifikan untuk variabel $\mathrm{X}_{2}$ Kepemimpinan $0.013<$ $5 \%(0,013<0,05)$, dengan demikian to $<\mathrm{t} \alpha$, maka Ha (hipotesis alternatif) diterima dan Ho (hipotesis nihil) ditolak. Artinya variabel $\mathrm{X}_{2}$ Kepemimpinan secara parsial berpengaruh signifikan terhadap kinerja karyawan di PT Bina San Prima.

\section{g. Analisa Regresi Linier Berganda}

Untuk mengetahui pengaruh variabel bebas (Insentif dan Kepemimpinan) terhadap variabel terikat (kinerja karyawan) di PT Bina San Prima, digunakan rumus regresi linier berganda. Rekapitulasi hasil analisa regresi linier berganda dapat dilihat pada tabel berikut:

Tabel

Hasil Pengujian Analisa Regresi Linier Berganda

Coefficients $^{\mathrm{a}}$

\begin{tabular}{|c|c|c|c|c|c|c|}
\hline \multirow{2}{*}{\multicolumn{2}{|c|}{ Model }} & \multicolumn{2}{|c|}{$\begin{array}{c}\text { Unstandardized } \\
\text { Coefficients }\end{array}$} & \multirow{2}{*}{$\begin{array}{c}\begin{array}{c}\text { Standardized } \\
\text { Coefficients }\end{array} \\
\text { Beta }\end{array}$} & \multirow[t]{2}{*}{$\mathrm{t}$} & \multirow[t]{2}{*}{ Sig. } \\
\hline & & $\mathrm{B}$ & Std. Error & & & \\
\hline \multirow{3}{*}{1} & (Constant) & 23.701 & 3.183 & & 7.446 & .000 \\
\hline & Insentif & .264 & .083 & .433 & 3.180 & .003 \\
\hline & Kepemimpinan & .308 & .119 & .353 & 2.594 & .013 \\
\hline
\end{tabular}

a. Dependent Variable: Kinerja Karyawan

Sumber : Hasil Pengolahan Data 
Berdasarkan data-data pada tabel di atas, maka dapat dihasilkan persamaan regresi linier berganda, yaitu : $\mathbf{Y}=$ $23.701+0.264 X_{1}+0.308 X_{2}$ Dalam persamaan regresi tersebut diketahui konstantanya adalah 23.701 ini dapat diartikan bahwa tanpa adanya Insentif $\left(\mathrm{X}_{1}\right), \quad$ dan Kepemimpinan $\left(\mathrm{X}_{2}\right)$, maka kinerja karyawan (Y) menunjukkan nilai sebesar 23.701 poin/satuan.

Koefisien regresi $\mathrm{X}_{1}$ (0.264), artinya jika insentif nilainya dinaikkan 1 point/satuan, sementara kepemimpinan nilainya tetap, maka kinerja karyawan (Y) akan naik 0.264 point/satuan. Koefisien regresi $\mathrm{X}_{2}$ (0.308), artinya jika kepemimpinan nilainya dinaikkan 1 point/satuan, sementara budaya organisasi nilainya tetap, maka kinerja karyawan (Y) akan naik 0.308 point/satuan.

\section{KESIMPULAN}

Berdasarkan hasil penelitian yang telah dilakukan untuk mengatahui Analisa Pemberian Insentif, dan Kepemimpinan, terhadap Kinerja Karyawan di PT Bina San Prima. Maka dapat ditarik kesimpulan sebagai berikut: hasil analisa koefisien korelasi dan analisa koefisien korelasi berganda didapatkan nilai koefisien korelasi Insentif adalah
0.667, dan nilai koefisen korelasi Kepemimpinan adalah 0.640, dengan demikian Insentif dan Kepemimpinan berpengaruh kuat dan signifikan $(0,000<0,05)$ terhadap Kinerja karyawan di PT Bina San Prima. Serta dari analisa koefisien korelasi berganda didapatkan nilai koefisien korelasi berganda $\mathrm{X}_{1}$ (Insentif) dan $\mathrm{X}_{2}$ (Kepemimpinan) adalah 0.717 , dengan demikian Insentif dan Kepemimpinan berpengaruh kuat terhadap Kinerja karyawan di PT Bina San Prima. Dan untuk analisa koefisien penentu (KP) didapat hasil sebesar 0,515 dengan demikian Insentif dan Kepemimpinan memiliki kontribusi sebesar 51,5\% terhadap Kinerja karyawan di PT Bina San Prima, dan sisanya sebesar $48,5 \%$ dipengaruhi oleh faktor-faktor lain yang tidak penulis teliti, misalnya, beban kerja, motivasi, dan pelatihan.

Selanjutnya Uji hipotesis dengan uji $\mathrm{F}$ didapatkan nilai sig. $\mathrm{F}$ hitung sebesar $0.000<5 \%$, $(0.000<0.005)$ sehingga dapat disimpulkan bahwa : Insentif dan Kepemimpinan secara simultan berpengaruh signifikan terhadap Kinerja karyawan di di PT Bina San Prima.Sedangkan berdasarkan uji hipotesis dengan uji $t$ didapatkan nilai signifikan masing-masing 0,003 dan $0.013<$ 0.05 sehingga dapat disimpulkan bahwa:Insentif secara parsial berpengaruh signifikan terhadap 
kinerja karyawan di PT Bina San Prima, demikian juga Kepemimpinan secara parsial berpengaruh signifikan terhadap kinerja karyawan di PT Bina San Prima.

\section{DAFTAR PUSTAKA}

Anwar Prabu Mangkunegara, 2013, Manajemen Sumber Daya Manusia Perusahaan, Cetakan kesebelas, Penerbit Remaja Rosda Karya, Bandung, 172 halaman.

J. Supranto, 2008, Statistika Teori dan Aplikasi, Jilid Satu, Edisi Ketujuh, Penerbit Erlangga, Jakarta, 392 halaman.

Kartini Kartono, 2008, Pemimpin dan Kepemimpinan, PT. RajaGrafindo Persada, Cetakan kelima, Jakarta

Malayu SP. Hasibuan, 2006, Manajemen Sumber Daya Manusia, Edisi Revisi, Penerbit Bumi Aksara, Jakarta

Moh. Pabunda Tika, 2008, Budaya Organisasi dan Peningkatan Kinerja Perusahaan, penerbit Bumi Aksara, Jakarta

Sedarmayanti, 2009, Sumber Daya Manusia dan Produktivitas Kerja, CV Mandar Maju, Bandung.

Sihotang, A., 2007, Manajemen Sumber Daya Manusia, Cetakan Pertama, PT. Pradnya Paramita, Jakarta, 415 halaman.
Sondang P. Siagian, 2008, Manajemen Sumber Daya Manusia, PT. Bumi Aksara Jakarta, 275 halaman.

Sugiono, 2010, Metode Penelitian Kuantitatif Kualitatif dan R\&D, Penerbit Alfabeta, Bandung

T. Hani Handoko, 2008, Manajemen Personalia dan Sumber Daya Manusia, BPFE, Yogyakarta. 